\title{
Evaluation Program of Physical and Health Educational Learning in Junior Secondary School in The Gayo Lues Region of Aceh
}

\author{
Rani Fitria \\ Sports Science Graduated Program \\ Yogyakarta State University \\ Yogyakarta, Indonesia \\ rani0073pasca2016@student.uny.ac.id
}

\begin{abstract}
This study evaluated the learning process, which aimed to explore the appropriateness of planning the learning process, the learning process of execution, and the evaluation of the standard of a physical and health education learning outcome process. The data comes from the physical and health teachers and the headmaster or the deputy headmaster. Data was collected by 1) observation, 2) interview, 3) documentation and 4) questionnaire. One technique of data analysis was inductive. The data were analyzed using qualitative descriptive analysis that included data collection, data presentation, data reduction, and inference.
\end{abstract}

Keywords-program evaluation, physical and health educational learning

\section{INTRODUCTION}

It is necessary to improve the quality of education in order to raise the level of education, which means that some components work together to achieve the goal. An educational program is a deliberate action to achieve the goal. An improvement in learning is one goal of a learning process [4]. that improving learning results from the teacher's development and the interaction between teaching and learning. Professionalism and the level of the teacher influence the quality of the training. The teacher as the educator must fulfill the pedagogical purpose.

In fact, there are some problems in the learning process. Some factors that may cause poor quality of the learning process are: a) less motivation of the students, b) unmotivated teachers, c) disadvantage of learning material, d) inadequate learning and assessment system, e) inappropriate means, f) inadequate management system [7].

These factors show that the learning process planned by the teacher must be considered for learning success. A teacher must have the appropriate competence to fulfill his responsibilities. [5] states that sometimes the school does not care about students with bad discipline; therefore, they finally reject the school process and drop out of school or leave school. The learning process is described in the Order No. 41 of the Ministry of Education of Indonesia in 2007 verse (1) the standard procedure for the elementary and middle school includes learning planning, implementation, learning, learning outcomes and the assessment of properly defined learning. Along with this verse, the teacher should prepare the lesson plan. The teacher must have a learning method to increase the quality of learning. In this case, the author tries to judge the execution of the learning and the result of the learning, if the learning process is suitable. As [10] said, a rating can be given as a process of decision-making using certain information through the learning outcome per test instrument and without evidence.

Some facts in the field, teachers of physical education and health take an inappropriate program of the Internet whenever the classroom plans. The inclined execution is the application of the lesson plan. Learning includes the launch activity, the main activity, and the completion activity. Physical education teachers and health teachers do not notice these components.

When learning physical and health education, the teacher does not pay attention to the introduction of learning, the main activity, and graduation activity. The No. 41 Regulations of the Indonesian Ministry of Education in 2007 on the standard process, explains that planning process syllabus and teaching includes the theme of identity, standard competition bring, skills, competence indicators, learning the purpose, learning material, time allocation, learning method, learning activity, score and learning source. The score of the study result is usually inconsistent and not well planned. To collect the result and information from the learning and assessment program, the writer uses the pile appearance evaluation model. Robert E. Stake presents this model. According to [9], the stake identifies 3 levels of program evaluation in education; Background, Transaction, and Result.

Based on the above-mentioned problems, the author formulates the problems of knowing the result of the teaching program of the physical education teacher in Blangkejeren district using three approaches.

The objectives of this research are to know the physical and health education curriculum to provide information on the performance of physical and health didactic learning in order to provide a clear description of the physical and health education learning outcomes in the Blangkejeren secondary school district. Learning physical and health education is a learning process for students through a series of planned activities; until the students gain material competence in physical and health education.

From these explanations, it can be concluded that physical and health education is a teacher's application process involving many components such as planning, curriculum, media, infrastructure, assessment, and the environment. In 
addition, the teacher must pay attention to the preparation of the students to support the learning process. In this case, the teacher, as an intermediary, must conduct effective teachinglearning in order to achieve the learning goal.

The execution of learning is the application of a lesson plan. Corey (in Sagala S, 2003: 61) states that learning is a process of an environment involved in learning to create a situation where an experience is given to help students solve a problem.

Based on the Ministry of Education of Indonesia number 41 the year 2007 on the standard process for the primary and secondary unit, says that the requirements of the application of the learning process are as follows. (1) A class size for the high school is 32 students. (2) The teaching time for the teacher who teaches in one week is 24 hours. (3) The proportion of student textbooks. Student for each subject is 1 : 1, (4) Teacher must understand the steps of class leadership.

The rating generally assumes a proportional learning measure activity. Scoring is an activity to measure the success of the learning action. One row of Government Decree No 19 of 2005 on National Education Standards states that qualification in education is an activity to gather and process the information to determine students' learning performance.

\section{EVALUATION PROGRAM}

The evaluation program is a systematic and objective qualification for a program that is carried out or has already been carried out in the execution and design of results. The purpose of the evaluation of the program is to determine the relevance and performance, efficient, effective, impact and continuity, in order to provide a reliable and meaningful assessment, a decision (World Bank, 2004: 13) to information. In addition, Musa (2005: 23) specifies that the evaluation program is an activity for a description of an object that has been made correctly, systematically and clearly. The evaluation is an attempt to collect, process and analyze data and information. The evaluation always refers to a decision because the result of the evaluation is the basis for evaluating a program and deciding on a well-organized or poorly organized program.

According to Arikunto \& Cepi [2], the starting point of the evaluation program is the curiosity to find the program's success. When the goal is achieved, the quality of the program is tested to find the reasons for success. Otherwise, the rating program will be used to see that the program has been reached. Pietrzak (in Solihat, 2007: 53) notes that some of the factors that cause the evaluation program have to be applied; First, the evaluation can identify the strength and weakness of a program that provides a basis for improving the program. Second, the assessment is used to analyze the effectiveness of a program.

Based on these definitions, therefore, an evaluation program can be closed as a systematic approach, collecting, measuring, analyzing and interpreting information as an effort to get the program description to the target procedure.

\section{EDUCATION REVIEW}

The educational review is an action or activity that is used to determine all educational components. Ahman and Glock
(1981: 153) said that pedagogical evaluation is a systematic process to obtain clear evidence of the effectiveness of education. This rating can be applied in progress and in the last run of the program. The ongoing evaluation of the program is referred to as formative evaluation, while in the last program it is known as summative evaluation. The formative evaluation serves to recognize the achievement of the learning objective. However, summative assessment is used to know the level of student achievement in all aspects of a subject. The aim is to obtain clear evidence of the effectiveness of the learning program.

\section{EVALUATION MODEL}

The evaluation model is a design evaluation model created by the expert. It is commonly called the same as its creator or step of its creation [9]. This model is adopted as the default or standard label of its owner. In the educational assessment, there are many types of models that can be used to evaluate a program. Even if the difference is between them, the author has collected data or information related to the object being evaluated and intends to prepare the material for making decisions about the next program.

The CIPP assessment model presented by Stufflebeam \& Shinkfield [8] is a structured, decision-oriented assessment approach that helps the administrator or executive to make a decision. Stufflebeam notes that the outcome of the evaluation will be an alternative problem solution for policymakers. The CIPP evaluation model is divided into four parts.

1. Content rating to serve the planning decision. An evaluator must carefully and accurately identify the assessment context associated with the planning decision, identify a need and formulate the program's objective.

2. Registration decision to structure the rating. All components associated with the process of the evaluation application must be well prepared. An input evaluation is given to help in the decision to identify the sources, to find the alternative, to make an organized planning, to give a strategy and to prepare the workflow.

3. Assessment of the process of implementing the decision. It is related to the implementation of the program. Some questions must be answered with the evaluation. For example, is the plan suitable for execution? Does the application of the program need to be improved? Therefore, the program can be monitored, controlled and improved.

4. Evaluation of the product for the recycling decision. The evaluation of the result is used to determine the next program. The goal that people can achieve is related to the program. It has an impact on this program. Evaluate the result in terms of the effect of the applied program.

The decision and responsibility of a program is the goal of this model. The assessment model in this step is to demarcate, preserve, sustain and deliver to all decision makers. The focus is on standard matrix scoring and Criterion matrix scoring. 


\section{INSTRUMENT OF STUDY}

Based on the purpose of the evaluation, which examines the training program for physical and health, the evaluation study model uses the stake model, which is the input, process, and outcome. Each step is divided into two steps, the description, and assessment. This stake model focuses on decision-oriented and reality-oriented technique in each evaluation focus, which is collected through the matrix of order effects of cases. The evaluation focuses on three parts, firstly the background assessment of the lesson plan process, which includes the development of the curriculum, the principles of the lesson plan, and the development of a lesson plan. Second, the transaction evaluation that the learning application contains the learning request and the learning application! Third, the evaluation of the product of learning outcomes, which includes the scoring objective, the scoring method, and the scoring principle!

A qualitative descriptive analysis is used in this study as a data analysis technique. They are data collection, data presentation, data reduction, and inference. The aim of this study is to assign the teachers who are assigned to some tasks as teachers of physical and health education.

The instruments used in this study are 1) observation, 2) interview, 3) documentation and 4) questionnaire. The sources of the data are a teacher, a headmaster (headmaster and a replacement at the beginning of the school).

\section{A. Observation}

According to Herdiansyah (2015: 132), the observer observes the behavior and the goal of the study. The aim of the observation is to describe the observed environment, activities, people and all individual behaviors in this case.

\section{B. Interview}

The template is used to format your paper and style the text. All margins, column widths, line spaces, and text fonts are prescribed; please do not alter them. You may note peculiarities. For example, the head margin in this template measures proportionately more than is customary. This measurement and others are deliberate, using specifications that anticipate your paper as one part of the entire proceedings, and not as an independent document. Please do not revise any of the current designations.

\section{Documentation}

The documentation consists of data or variables in a report, a $\log$, an agenda, etc. The documentation watched the inanimate. The documentation is used to reinforce the data obtained from the interview and direct observation or other data collection techniques. This tool is used to customize the observation, interview, and questionnaire data.

\section{Questionnaire}

The author uses a few questions that are consistent with the instrument grid. The instrument grid is based on the references and has been validated by the expert. Every respondent who has a different question adapts to his or her own function. In addition, the question can be used as information to measure the data contained in the context, input, process and result or product.

\section{CONCLUSION}

Based on the outcome of the study, to see the appropriateness of all aspects of physical education and health learning, which will be used as a measurement tool to evaluate the learning program in this study, the author expects this to be in the planning, application, and qualification of physical and health education Learning is done based on the standard process.

The headmaster should guide the teacher in developing a lesson plan based on the subject matter. Then, each new academic year, policymakers should hold a workshop and implement the criteria of a standard process for better quality learning and teaching.

\section{REFERENCES}

[1] Ahman \& M. Glock, Evaluating student progress: principles of test and measurements. Boston: Allyn and Bacon. 1981.

[2] S. Arikunto, \& S. A. J. Cepi, Evaluasi program pembelajar-an. Jakarta: PT Bumi Aksara. 2009.

[3] Depdiknas. Kurikulum berbasis kompetensi:Kompetensi dasar pendidikan jasmani SD dan MI. Jakarta: Pusat Kurikulum, Balitbang DEPDIKNAS. 2004.

[4] Dimyati \& Mudjiono. Belajar dan pembelajaran. Jakarta: Rineka Cipta. 2002

[5] Hargreaves \& Raynolds. Education controversies and critiques. London: The Falmer Press. 1986.

[6] H. Herdiansyah, Metodologi penelitian kualitatif untuk ilmu psikologi. Jakarta: Salemba Humanika. 2015.

[7] N. Sudjana, Penilaian hasil proses belajar mengajar. Bandung: PT Remaja Rosdakarya. 2006.

[8] D. L. Stufflebeam, and A. J. Shinkfield, Systematic evaluation: A selfinstructional guide to theory and practice. Boston: Kluwer-Nijhoff Publishing. 1985.

[9] Tayibnapis, F.Y. Evaluasi program. Rineka Cipta. Jakarta. 2000.

[10] Zainul \& Nasution, Penilaian hasil belajar. Jakarta: Dirjen Dikti. 2001. 